\title{
Conceptual foundations of legal support for engineering in Arctic studies of climatic changes
}

\author{
Nikolay Makhonko, Sergey Belousov, and Elena Tarasova \\ Saratov State Law Academy
}

\begin{abstract}
The article is devoted to the problems of the development of the Arctic as a territory of international cooperation, taking into account the national interests of individual states. The specificity of geopolitical, social, economic, and climatic conditions determines the need to develop conceptual foundations of legal support for the implementation of environmental engineering processes at the development of the Arctic and research on climatic changes of the region. The article analyzes the main strategic and legal documents regulating the implementation activities in relation to the technical and technological support in the question of the development of the Arctic territories and the preservation of climatic stability. The options for creating an adequate system of convergence of national and international legal regulation in the field of determining anthropogenic pollutants and fixing key indicators of the state of the Arctic environment are detailized and characterized. The scientific substantiation of the causes and consequences of climate change in the Arctic ecological systems is given. The advantages of scientific research with the use of modern engineering and digitalization methods, as well as the usage of information and communication technologies for the prompt exchange of environmentally significant information, are revealed. It is noted that the most topical issues, the national strategies for the development of the Arctic zones of the Russian Federation, Denmark, Norway, and Canada are of a similar nature. They have common approaches to the preservation of vulnerable Arctic ecological systems and the conceptual foundations of legal support for engineering in Arctic scientific research in the field of climate change and conservation.
\end{abstract}




\section{Introduction}

Traditionally, the development of the Arctic region was associated with the production of hydrocarbons and other types of mineral raw materials. Global changes in the world economy have led to the large-scale development of the Arctic territories by many states [12]. Recognized by the world community, the countries of the Arctic Five (Denmark, Norway, Canada, the United States of America, and the Russian Federation) were the first to develop national Arctic strategies and began to form "climate" legislation. New settlements, oil and gas and mining enterprises, infrastructure facilities of the seaports of the Northern Sea Route [9] appearance and also military bases construction had negative affection on the fragile Arctic systems and climatic stability. According to scientists, the uncontrolled socio-economic development of the Arctic territories has led to a decrease in the permafrost zone and the ice melting in the Arctic waters. The need for ecological monitoring of the state of the environment was a trigger for the development and implementation of the latest science-intensive technologies and methods of modern engineering in Arctic studies of climatic changes [1, 5, 14]. These processes required an adequate legislative platform in order to provide legal support for research activities using engineering methods. All types of activities in the Arctic cannot be carried out by states autonomously and without certain agreements of a bilateral or multilateral nature. In this regard, the issues of the implementation of international legal norms in the norms of national legislation are very relevant and require further elaboration.

\section{Study methodology}

The purpose of the article is to identify the features of the application of engineering methods in Arctic studies of climatic changes, as well as the variability of legal support for this activity, depending on the elaboration of the legislative framework at the national and international levels. The methodological basis of the research will include the general scientific method and special methods of cognition, such as comparative legal, environmental legal, statistical and empirical. The development of legal regulation of scientific, technical, and environmental substantiation of mechanisms of legal support for the development of the Arctic region has been studied. The degree of correlation between the norms of environmental law and the scientific achievements of natural and technical sciences has been investigated. The problems of creating a competitive environment in the field of the development of modern engineering methods in individual countries of the Arctic five are analyzed.

\section{Study results}

The change in the geopolitical interests of the leading countries with developed economic systems influenced the perception of the Arctic as a world mineral resource base. Recent decades climatic changes $[8,10]$ have significantly expanded the Arctic zones suitable for development. The Arctic countries [2] actively embarked on the economic development of their territories, stimulated the internal migration of the able-bodied population, 
and also expanded their military presence through the construction of military bases and the deployment of polar groupings of troops on them. The opened Northern Sea Route required the construction of seaports and all accompanying maritime infrastructure. To supply electrical power to new settlements and industrial enterprises, new energy facilities began to be built [4]. Such social and economic expansion endangered not only the preservation of the ecological systems of the Arctic, but also negatively affected the climatic stability of the region [7]. The world community was forced to unite efforts to protect the environment of the Arctic zone, taking into account national military-political and economic interests. The main trend in this activity was the almost simultaneous adoption of national strategies for the development of the Arctic and the development of legislation in the field of climate change. Table 1 contains the legislative support of individual countries of the Arctic Five in the field of development of these territories and the preservation of climatic stability.

Table 1. Legislation of individual countries of the Arctic Five on the development of the Arctic and climate change.

\begin{tabular}{|c|l|l|}
\hline Countries & $\begin{array}{l}\text { National strategies of the } \\
\text { Arctic development }\end{array}$ & \multicolumn{1}{c|}{$\begin{array}{c}\text { National Climate Change } \\
\text { Legislation }\end{array}$} \\
\hline Denmark & Danish Arctic Strategy 2011 & $\begin{array}{l}\text { Climate Act to Reduce Greenhouse } \\
\text { Gas Emissions, 2019 }\end{array}$ \\
\hline Norway & $\begin{array}{l}\text { Norway's Arctic Strategy - } \\
\text { Between Geopolitics and } \\
\text { Social Development, 2017 }\end{array}$ & $\begin{array}{l}\text { Conservation Act, 1970 } \\
\text { Environmental Pollution Control Act, } \\
1981 \text { Greenhouse Gas Emissions } \\
\text { Trading Act, 2004 }\end{array}$ \\
\hline Canada & $\begin{array}{l}\text { Canada's Northern Strategy, } \\
2009\end{array}$ & $\begin{array}{l}\text { Canadian Environmental Assessment } \\
\text { Act, 1992 } \\
\text { Canadian Environmental Protection } \\
\text { Act, 1999 }\end{array}$ \\
\hline Russia & $\begin{array}{l}\text { Strategy for Developing } \\
\text { the Russian Arctic Zone } \\
\text { and Ensuring National } \\
\text { Security until 2035, 2020 }\end{array}$ & $\begin{array}{l}\text { Climate Doctrine of the Russian } \\
\text { Federation, 2009 } \\
\text { On measures to implement the state } \\
\text { scientific and technical policy in the } \\
\text { field of environmental development of } \\
\text { the Russian Federation and climate } \\
\text { change, 2021 }\end{array}$ \\
\hline
\end{tabular}

A comparative analysis of the degree of environmental and legal support for the elaboration and development of the Arctic region as a zone of peace and cooperation shows that each of the countries under discussion has fully developed their national strategies for the development of the Arctic. It should be noted that the strategies of the Russian Federation [6], Denmark, Norway, and Canada are harmonized and have a common theoretical and ideological platform in relation to environmental protection, preservation of biocenoses, and "fragile" ecological systems of the Arctic. The Kingdom of Denmark presented its strategy for the Arctic as a joint document of the commonwealth of Denmark, Greenland, and the Faroe Islands, which determined its originality. The Danish Parliament passed a Climate Act in 2019 to reduce greenhouse gas emissions and achieve carbon neutrality by 2050. In this regard, Denmark is actively promoting the use of engineering methods to protect the Arctic environment and stabilize climate change. For 
example, the leading Technical University of the Kingdom of Denmark is working on a government order to create innovative methods of environmental monitoring and calculation of scenarios of the negative impact of climate change in the Arctic. Norway is one of the recognized leaders in the formation of the national Arctic policy. In 2006, the government of the Kingdom of Norway published for the first time a national strategy for the northern regions. The advantages of the strategy include the call for the development of partnership with the Russian Federation. Three years later, the strategy was updated, it became known as 'New Structural Elements in the North'. In this version, the necessary issues of studying the climate and the development of a special system of engineering education specifically for the Arctic were set out. The "Arctic Strategy of Norway - Between Geopolitics and Social Development" (2017), indicated in Table 1, declared the efforts of the state to develop its Arctic zone as the most innovative and sustainable region of the country. The provisions of the strategy fixed the priority directions in the development of the Arctic territories: the introduction of science-intensive engineering projects in the study of climate change and the preservation of the quality of the environment in the region; implementation of high-tech modernization of the system of environmental monitoring and monitoring of potential emergencies; the development of Arctic infrastructures is differentiated in relation to the sectors of the economy. Special attention is paid to the development of international cooperation, especially in interaction with neighboring states. The national legislation in the field of climate change is represented by three main normative legal acts: Svalbard Environmental Protection Act, Pollution Control Act, Greenhouse Gas Emission Trading Act. These legislative acts developed in accordance with the main world trends in the field of environmental protection and preservation of climatic stability. Canada identifies the Arctic as a region of strategic importance. The natural resources located on this territory are considered as the dominant in the energy independence of the country's economy ensuring. Despite the militarypolitical interests and economic feasibility, the Canadian government is building its foreign policy towards the peaceful development of the Arctic and is fundamentally in favor of coordinated international cooperation in the region. The legal issues of Earth climate change are addressed in Canadian legislation in separate sections of two specialized acts - the Canadian Environmental Protection Act and the Canadian Environmental Assessment Act. In Russia, the Climate Doctrine of the Russian Federation was adopted in 2009. The experts note the quality and scientific character of this document. Thus, the theoretical basis of the Doctrine is a deep and comprehensive analysis of scientific research in the following areas: the results of environmental monitoring (the territory of the Russian Federation and the territory of other regions); diversified research on climate change; forecasting pessimistic and optimistic consequences of the impact of climate change on the spheres of the economy, social development and the general state of the environment of the Arctic region. The Doctrine highlights scientifically based climate responses to anthropogenic impact and the usage of special measures to reduce such anthropogenic load. The developers of the Climate Doctrine of the Russian Federation note the need to take timely measures to adapt to changes in climate stability. At present, the efforts of the state are aimed at strengthening the balance of social, economic, and 
environmental conditions for the life of the population. In order to ensure the reduction of the level of greenhouse gas emissions, systematic research activities are required to determine the issuers and objects of absorption of greenhouse gases. To achieve these goals, it is necessary to develop technologies and methods of modern environmental engineering. The scientific community with the assistance of the international organization Arctic Council has developed and implemented the Arctic Monitoring and Assessment Program (AMAP) [13]. Note that this Program has an international status. The developers of the Program have identified the main scientific and applied areas: environmental monitoring of the Arctic zone; mapping of pollutants; allocation of territories of representativeness for each of the countries of the Arctic Five, creation of a modern information system, and identification of promising engineering methods that are adequate to the level of scientific research on the ecological and climatic problems of the Arctic. Table 2 shows the individual countries that have signed the Arctic Environmental Protection Strategy (AEPS) and included in the Arctic Monitoring and Assessment Program (AMAP), the main regulations, and the vector of development in the long-term Arctic monitoring project.

Table 2. Arctic Monitoring and Assessment Program (AMAP).

\begin{tabular}{|c|c|c|}
\hline $\begin{array}{c}\text { Countries participating } \\
\text { in the program }\end{array}$ & Regulatory framework & $\begin{array}{c}\text { Directions of Arctic } \\
\text { monitoring }\end{array}$ \\
\hline Denmark & \multirow{4}{*}{$\begin{array}{l}\text { Arctic } \\
\text { Environmental Protection } \\
\text { Strategy (AEPS), 1991; } \\
\text { Arctic Monitoring and } \\
\text { Assessment Program } \\
\text { (AMAP), 1991; } \\
\text { Ilulissat Declaration (on } \\
\text { Environmental Regulation } \\
\text { in the Arctic), 2008; }\end{array}$} & \multirow{4}{*}{$\begin{array}{l}\text { - determination of } \\
\text { anthropogenic pollutants; } \\
\text { - consolidation of key } \\
\text { indicators of the state of } \\
\text { the Arctic environment; } \\
\text { - establishing the causes } \\
\text { and consequences of } \\
\text { climate change in Arctic } \\
\text { ecosystems; } \\
\text { - research using modern } \\
\text { engineering methods; } \\
\text { - information and } \\
\text { communication } \\
\text { technologies usage for the } \\
\text { operational exchange of } \\
\text { environmentally significant } \\
\text { information. }\end{array}$} \\
\hline Norway & & \\
\hline Canada & & \\
\hline Russian Federation & & \\
\hline
\end{tabular}

The authors focus on the totality of scientific messages in the implementation of environmental monitoring of the Arctic region. One of the international scientific groups is constantly monitoring the anthropogenic changes in the environment associated with the social and economic development of the Arctic. Indeed, the economic exploitation of natural resources, the destruction of ecological systems and biocenoses directly depend on the growth of settlements, the development of industrial and energy facilities, the uneven distribution of the permanently living and arriving population. Another scientific group records and analyzes all the changes that are caused by natural phenomena in the Arctic zone. The main threats to the fragile Arctic systems include climate change, which is caused by global warming and the consequences of the destruction of the Earth's 
ozone layer. The third message is environmental engineering. The resulting aggregate environmental monitoring data are sent to national scientific centers for analysis and processing in order to determine the options for the inclusion of engineering methods in environmental protection processes and forecasts of adverse changes in the Arctic ecosystem that are typical for a particular country. Arguing about the need to apply engineering methods in modern environmental protection measures, it is necessary to highlight the existing terms that define such a scientific phenomenon as engineering. Experts rightly point out that various types of engineering and technical activities fall under the definition of "engineering": engineering protection of the environment, environmental engineering, ecological engineering, that is, a set of scientific and engineering principles for preserving and improving the quality of the environment. Defining the technical methods of Arctic studies of climate change, the authors dwell on the term Ecological Engineering, which combines the features of an applied discipline, combining environmental and technical sciences, regulated by law. Applied ecology is aimed at studying the mechanisms leading to the destruction of universal ecological ties in human economic activities and ways to prevent such activities. It combines the following scientific areas: the ecology of the biosphere; geoecology; mathematical ecology; economic ecology; legal ecology; ecological engineering; social ecology; human ecology and others. The development and systematization of knowledge in ecological engineering are carried out in close relationship with all the scientific disciplines that form environmental science. So, ecological engineering uses the system of knowledge, information, and information of a wide range of disciplines of environmental science in order to train qualified personnel. Studying the patterns of environmental sciences, the applied discipline - ecological engineering studies social processes and problems connected with environmental protection during human production activities in order to organize a more rational use of natural resources and environmental protection, ensure environmental safety, while relying on theoretical fundamentals of engineering sciences (in the design and construction of technical devices). Atmospheric air is an essential component of the environment that influences climatic changes in the Arctic systems as a result of the economic and social development of the Arctic. In Table 3, the authors provide a list of natural and anthropogenic sources of air pollution and the corresponding engineering and technical methods of air protection.

Table 3. Types of issuers of ecotoxicants of atmospheric air in the Arctic and combined methods of its protection.

\begin{tabular}{|c|c|c|}
\hline $\begin{array}{c}\text { Issuers of natural } \\
\text { ecotoxicants }\end{array}$ & $\begin{array}{l}\text { Anthropogenic } \\
\text { issuers and } \\
\text { ecotoxicants }\end{array}$ & $\begin{array}{l}\text { Engineering and } \\
\text { technical methods of } \\
\text { atmospheric air } \\
\text { protection }\end{array}$ \\
\hline volcanic eruptions & industry & \multirow{5}{*}{$\begin{array}{l}\text { environmental monitoring; } \\
\text { innovative technologies; } \\
\text { the latest information and } \\
\text { communication systems; } \\
\text { environmental regulation; }\end{array}$} \\
\hline dust storms; & transport; & \\
\hline forest fires; & energy facilities; & \\
\hline dust of space origin; & aviation; & \\
\hline natural disasters; & sprays & \\
\hline
\end{tabular}


It is well known that there are two main sources of air pollution: natural and anthropogenic. Natural sources of air pollution, which are considered as background pollution and change slightly over the years, include:

- volcanic activity, during volcanic eruptions, a huge amount of hot gases, ash, water vapor is thrown into the atmospheric air, which are picked up and moved by air currents over huge distances. Volcanic emissions can be present in the ambient air for many years;

- dust storms, in which dust and sand are lifted into the atmosphere by prolonged and strong winds blowing out the upper layers of the soil;

- forest fires caused by the ignition of forest litter, herbaceous shrubs, tree crowns, peat layers, plant roots with the release of volatile ecologically hazardous compounds (foggy resin, phenols, organic acids, gases), which are carried over long distances by the wind and pollute the atmospheric air;

- dust of space origin, filling interstellar, interplanetary and near-earth space, falling onto the Earth's surface in the form of solid particles ranging in size from fractions of a micron to several microns;

- natural disasters, defined as global catastrophes occurring under the influence of destructive atmospheric processes.

Anthropogenic sources of atmospheric pollution include:

- industry, that is, industrial production, which has a huge impact on the level of development of economic, political and social indicators of the state, is the main source of air pollution. So, metallurgical processing enterprises, cement plants emit toxic gases into the atmosphere (nitrogen oxides, hydrogen sulfide, chlorine, etc.);

- transport, since in the process of fuel combustion during the operation of vehicles, there is an intense pollution of atmospheric air in megalopolises, the level of pollution in the total air pollution during the operation of vehicles reaches $40 \%$;

- energy facilities, such as thermal power plants, household boilers, power plants operating on coal, fuel oil, diesel fuel, natural gas and gasoline, emit sulfur dioxide and carbon dioxide, as well as other toxic gases into the atmospheric air together with smoke;

- aviation equipment that ejects pollutants into the atmosphere or burns oxygen from the atmospheric air;

- aerosols containing gaseous fluorocarbons that damage the ozone layer.

Environmental monitoring takes a key place among the engineering and technical methods of the atmospheric air protection [3]. Until a certain time, the European countries and the Russian Federation were engaged in the development of the environmental monitoring system, quite autonomously. In 1996, the European scientific community for the first time started talking about an integrated system for tracking and analyzing information in order to control air pollution (Council Directive of the European Union 96/61/EC, 1996). In connection with the signing of the Paris Climate Agreement, the Russian Federation has stepped up international activities to improve the technical characteristics of equipment for Arctic monitoring. Despite the apparent chronological discreteness in the protection of the Arctic environment, Russia and the countries of Europe have developed common approaches to the technical equipment of continuous monitoring systems. The introduction of the latest technologies in the countries of the Arctic five occurs almost simultaneously, and the very complication of climate 
technology is based on the principles of additivity. Such international efforts make it possible to synchronize the study of climate change processes [11] and specify the levels of anthropogenic load on vulnerable Arctic ecosystems. Innovative industrial technologies are the basis of an ecologically developed state. As a result of this development, there is a need for the development and implementation of advanced technologies in order to protect atmospheric air from pollution. Accordingly, in all states, measures are being taken that contribute to maintaining the quality of the environment, optimal for the life of the population. These include technologies and production cycles aimed at reducing the intensity of pollutant emissions. Modern modernization of production processes and the development of the latest equipment that does not cause critical levels of air pollution creates the basis for recycling industries. The tasks of ecological engineering include tracking the implementation of a technological line: processing and neutralizing pollutant emissions by special purification systems - installing devices and systems for cleaning gas emissions from technical impurities - industry standardization of atmospheric air quality - regulating the volumes and levels of the chemical, physical and biological effects. However, in practice, according to scientiststechnologists, the most effective are the combined methods of cleaning emissions, such as physical absorption, chemisorption, thermal neutralization, and catalytic cleaning of waste gases. Timely analytical processing of the most important environmental indicators is impossible without the latest information and communication systems. The development and implementation of advanced information technologies allow real-time monitoring of failures in technological production processes and promptly eliminating the potential danger of uncontrolled emissions of pollutants into the air regardless of climatic factors and background conditions. Legislative consolidation of the introduction of information and communication technologies makes it possible to dynamically integrate the latest digitalization methods into environmental monitoring of emissions of ecotoxicants into the environment and stabilize the processes of climate change in the Arctic. The regulation of the entry of pollutants into the atmosphere contributes to the development of an optimal model for organizing complex technological processes. The legislator proposes separate options for the legal consolidation of safety regulations and the establishment of environmental standards, depending on economic and industry characteristics. At present, technical and legal norms are the basis for the regulation of the intake of pollutants into the atmosphere. Note that technical standards are rules governing the relationship of people with the means of production, technology and the environment, which determine the best methods, techniques and means of handling natural and artificial objects, as well as the sequence and content of technological operations. In this case, a technical rule, taking the form of a legal norm, becomes a generally binding rule, a legal norm with a technical transparent content (technical and legal norm).

\section{Discussion of results}

The study and analysis of the regulatory legal framework in the field of legal support for engineering in Arctic studies of climate change determine the possibility of discussion on the economic justification for the development of 
the Arctic territories and the environmental consequences of such development on vulnerable Arctic systems and climatic stability. The team of authors got acquainted with the opinions of distinguished scientists with great interest and is ready to discuss the proposed discussion issues. It can be assumed that the trends in the development of the legislative framework of individual countries of the Arctic five in the field of climate change will become controversial. European legislation, the legislation of Canada and the Russian Federation demonstrate the wide application of environmental engineering methods in the development of the Arctic territories and the study of climatic stability. The question of the degree of environmental and legal support for the exploration and development of the Arctic region as a zone of peace and international cooperation remains open. In this case, it can be noted that there is no irreconcilable contradiction between the national strategies of the countries of the Arctic region in terms of the use of engineering methods in the protection of the Arctic environment and the reduction of greenhouse gas emissions during the development of the region. The question of the need to unify the methods used to ensure the reduction of the level of greenhouse gas emissions, requiring systematic research activities to determine the issuers and objects of absorption of greenhouse gases, remains controversial. The world scientific community is actively discussing issues of long-term Arctic monitoring. The main areas of environmental monitoring in the Arctic are controversial: determination of anthropogenic pollutants; consolidation of indicators of the state of the environment in the Arctic; establishing the causes and consequences of climate change in Arctic ecosystems. Further, it's possible to discuss the balance of natural and anthropogenic sources of air pollution as one of the natural indicators of climate change. The most important issue remains the need for either autonomous or simultaneous and coordinated introduction of the latest technologies into production cycles and the development of industrial equipment that reduces the conventionally critical values of environmental pollution in the Arctic. The variability of the legislative consolidation of the introduction of information and communication technologies in the study and analysis of climate change processes caused by regular emissions of ecotoxicants that negatively affect biocenoses and ecological systems of the Arctic region is proposed for discussion.

\section{Conclusion}

The analysis performed allows us to draw the following conclusions and suggestions. The development of conceptual foundations of legal support for engineering in Arctic research was initially based on the pragmatic economic and political aspirations of individual Arctic states to obtain geopolitical preferences from the development of the Arctic territories. The research and industrial structures of various status of the countries of the Arctic five, involved in this process, came to the common conclusion that the 'spontaneous' development of the Arctic territories can not only increase the anthropogenic load on the ecological systems of the Arctic, but also negatively affect the climatic stability of the Earth. Firstly, the Arctic strategies of the Russian Federation, Denmark, Norway and Canada are quite harmonized and united by a common theoretical and ideological platform in relation to the conservation of biocenoses and vulnerable ecological systems 
of the Arctic. Secondly, these countries, despite the apparent temporal discreteness in the protection of the Arctic environment, have developed common approaches to the introduction of ecological engineering methods. The introduction of the latest technologies in the countries of the Arctic five occurs almost simultaneously, and the very sophistication of technology and equipment is based on the principles of additivity. Thirdly, modern European legislation, the legislation of Canada and the Russian Federation demonstrate the wide application of ecological engineering methods in the study of climate change and the development of science-intensive technologies to ensure climate stability. Fourth, when analyzing the regulatory, statistical and forecast data developed by the legislative and executive bodies of individual countries, international organizations, representatives of the industrial establishment, a long-term prospect was revealed for the development of conceptual foundations of legal support for ecological engineering in order to develop the Arctic region and study climate change.

Thus, taking into account the general and different features in the creation of international and national structures for the implementation of ecological engineering methods, legal support for this segment of international cooperation and the implementation of international environmental requirements in national laws and by-laws, it is necessary to solve the following problems:

1. Particular attention should be paid to the issues of correlation of technical and technological norms and rules, regulations for the use of modern methods of ecological engineering in all processes of the development of the Arctic territories and the study of climatic stability.

2. It is necessary to develop and adopt a package of normative legal acts, in which technical, technological and legal requirements for flagship models of climate studies, scientifically based mechanisms of adaptation to climate change and their consequences for the population of the country and its economy should be established and adopted.

3. Develop a balanced engineering system for identifying issuers and objects of absorption of greenhouse gases.

4. Russian participation in the work of specialized international organizations and specialized scientific groups on climate cooperation as part of bilateral and multilateral intergovernmental commissions should be expanded, which will improve national and international mechanisms for environmental monitoring.

A comprehensive solution to these problems will make it possible to declare the formation of a unified approach to the development and implementation of new generation ecological engineering methods in Arctic studies of climate change at the present time and in the long term.

\section{References}

1. M. Andrachuk, M. Marschke, Ch. Hings, D. Armitage, Biological Conservation, 237, 430 (2019)

2. A. Bancheva, Polar Science, 21, 23 (2019)

3. D. Barry, S. Hoyne, Implications for New Green Deal Era Current Opinion in Environmental Science \& Health, 100259. (2021) 
4. M. de Witt, H. Stefánsson, Á. Valfells, J. N. Larsen, Renewable Energy, 169, 144 (2021)

5. Hashem, A., Hossain, M.A. Motalib., Marlinda, Ab R., Mamun, M. Al., Simarani, K., M.R. Johan, Applied Surface Science Advances, 4 (2021)

6. C. Liu, Fan, Hou-Ming, Dang, Xiu-jing, X. Zhang, Russia's Arctic strategy Ocean \& Coastal Management, 201 (2020)

7. N.Ng. Saeed, K.Y. Adolf, Norway Maritime Transport and Regional Sustainability (2020)

8. Ch.R. Scotese, Song, H., Mills, Benjamin J.W., D. G. van der Meer, The earth's changing climate during the last 540 million years Earth-Science Reviews (2021)

9. V. Sergeev, I. Ilin, A. Fadeev, Transport and Logistics Infrastructure of the Arctic Zone of Russia Transportation Research Procedia, 54, 944. (2021)

10. Van Lange, Paul A.M., Huckelba A.L. Psychological Distance: How to Make Climate Change Less Abstract and Closer to the Self Current Opinion in Psychology (2021)

11. V. Vinogradova, T. Titkova, A.Zolotokrylin, How climate change is affecting the transitional natural zones of the Northern and Arctic regions of Russia Polar Science, 100652. (2021)

12. X. Wei, J. Xiao, Z. Wang, Z. Wang, Y. Tian, Integration and development of energy and information network in the Pan-Arctic region Global Energy Interconnection, 2, 504 (2019)

13. F. Wong, H. Hung, H. Dryfhout-Clark, W. Aas, P. Bohlin-Nizzetto, K. Breivik, Mastromonaco, Michelle Nerentorp, L., Eva B., Ólafsdóttir, K., Sigurðsson, Á., Vorkamp, K., Bossi, R., Skov, H., Hakola, H., Barresi, E., Sverko, E., Fellin, P., Li, H.,Vlasenko, A., Zapevalov, M., Samsonov, D., S. Wilson, Time trends of persistent organic pollutants (POPs) and Chemicals of Emerging Arctic Concern (CEAC) in Arctic air from 25 years of monitoring Science of The Total Environment, 775, 145109, (2021).

14. X. Zhang, K. Shu, S. Rajkumar, V. Sivakumar, Environmental Impact Assessment Review, 86 (2021). 